\title{
KEMISKINAN MULTIDIMENSI DI KOTA YOGYAKARTA
}

\author{
Pandu Baniadi \& Mustofa \\ Universitas Negeri Yogyakarta, Indonesia \\ 13804241042@student.uny.ac.id,mustofa@uny.ac.id
}

\begin{abstract}
Abstrak: Kemiskinan merupakan salah satu masalah yang terjadi di semua pembangunan daerah, termasuk di Yogyakarta. Persoalan kemiskinan bukan hanya terkait dengan masalah ekonomi, namun juga terkait dengan bidang lain yang sifatnya multidimensi. Penelitian ini bertujuan untuk mengetahui kondisi kemiskinan moneter, kemiskinan multidimensi, dan perbandingan antara kemiskinan moneter dan multidimensi di Kota Yogyakarta. Data yang digunakan dalam penelitian ini adalah data sekunder yang diperoleh dari Badan Pusat Statistik (BPS) Provinsi DIY dan sumber lainnya sebagai pendukung. Metode analisis yang digunakan dalam penelitian ini adalah metode analisis deskriptif. Hasil penelitian menunjukkan bahwa tingkat kemiskinan moneter di Kota Yogyakarta berada di angka 7,66\%, sedangkan angka kemiskinan multidimensi adalah $1,39 \%$. Kemiskinan multidimensi paling banyak terjadi pada indikator kepemilikan rumah. Perbandingan menunjukkan bahwa tren angka kemiskinan moneter cenderung menurun sementara multidimensi fluktuatif.
\end{abstract}

Kata kunci: kemiskinan, multidimensi

\section{MULTIDIMENTIONAL POVERTY IN YOGYAKARTA}

\begin{abstract}
Poverty is a problem which is faced by every region, including Yogyakarta. The matter of poverty is not only related to economic problems, but also the other majors which has multidimensional characteristic. This research aim to find out the condition of monetary poverty, multidimensional poverty, and the comparison between monetary poverty and multidimensional poverty in Yogyakarta. The data used is secondary data from D.I Yogyakarta's Indonesian Statistic Agency (BPS) and other related sources. While the analysis method that is used in this research is descriptive analysis method. The result of this research shows that number of monetary poverty in Yogyakarta is $7,66 \%$ while multidimensional poverty is $1,39 \%$. Multidimensional poverty is mostly happened by the indicator of house ownership. Comparison shows that the trend of monetary poverty is decreasing whereas the multidimensional poverty is fluctuating.
\end{abstract}

Keywords: poverty, multidimensional

\section{PENDAHULUAN}

Kemiskinan merupakan salah satu masalah yang harus diatasi setiap daerah. Persoalan kemiskinan bukan hanya terkait dengan masalah ekonomi, namun juga terkait dengan bidang lain yang sifatnya multidimensi. Pada tahun 2005-2010, penduduk miskin berhasil diturunkan rata-rata 816 ribu jiwa per tahun. Akan tetapi pada periode 2010-2015, hanya 486 ribu penduduk berhasil keluar dari kemiskinan tiap tahunnya. Per tahun 2015, masih ada 28,59 juta penduduk miskin di Indonesia (Iryanti, 2016:2).

Pemerintah mengalami kesulitan dalam upaya mengentaskan kemiskinan. Kesulitan dalam mengentaskan kemiskinan dikarenakan kurangnya pemahaman berbagai pihak tentang penyebab kemiskinan. Program penanggulangan kemiskinan selama ini hanya dilihat dalam satu dimensi saja. Sumber data yang digunakan pemerintah untuk menanggulangi kemiskinan secara makro berasal dari Survey Sosial dan Ekonomi Nasional (Susenas) yang dilakukan oleh Badan Pusat Statistik (Ras, 2013:57).

Amartya Sen pada tahun 1987 mengkritik pendekatan kemiskinan dengan menggunakan analisis moneter. Menurut Sen, pendekatan tersebut hanya memotret sebagian kecil dari begitu besarnya persoalan kemiskinan. Menurut Sen, masalah kemiskinan tidak hanya berkaitan dengan 
kemampuan daya beli (purchasing power parity), penghasilan atau konsumsi tapi terdapat dimensi yang lebih luas dari kondisi kemiskinan (Perkumpulan Prakarsa, 2013:2).

Pengukuran kemiskinan secara non moneter dapat memperlihatkan secara konkret apa yang disebut dengan kemiskinan itu sendiri. Pengukuran kemiskinan dengan menggunakan pendekatan moneter menunjukkan kegagalan dalam mengindentifikasi orang miskin dan indikator non moneter dapat diandalkan untuk memperlihatkan siapa yang disebut orang miskin (Alkire et all, 2015:8-9).

Studi yang dilakukan di berbagai negara menunjukkan bahwa pengukuran kemiskinan secara moneter sering menemukan hasil berbeda bila dibandingkan dengan kondisi yang dialami oleh penduduk miskin. Telah ditemukan bahwa 13\% rumah tangga di Montevideo Uruguay adalah penduduk dengan pendapatan miskin namun mampu memenuhi kebutuhan dasarnya. Sedangkan 7,5\% berada dalam kasus sebaliknya, mereka merupakan penduduk tidak miskin namun tidak mampu memenuhi kebutuhan dasarnya (Alkire et all, 2015:10).

Fenomena yang dialami oleh Indonesia dalam mengurangi penduduk miskin juga terjadi di Kota Yogyakarta. Dari tahun ke tahun, angka kemiskinan hanya turun sedikit. Angka kemiskinan Kota Yogyakarta tahun 2013 sebesar 37.400 atau 9,38\% dan jumlahnya menjadi turun menjadi 35.600 jiwa atau $8,67 \%$ di tahun berikutnya. Pada tahun 2015 jumlah penduduk miskin di Kota Yogyakarta malah naik menjadi 36.000 atau 8,75\% dari jumlah penduduk. Permasalahan kemiskinan di Kota Yogyakarta memang cukup kompleks. Dengan luas wilayah hanya 3250 hektar, Yogyakarta merupakan salah satu kota terpadat di Indonesia. Kepadatan penduduk di Kota Yogyakarta pada tahun 2015 mencapai 12.699 jiwa per $\mathrm{km}^{2}$ (BPS, 2017:67). Angka tersebut jauh lebih tinggi dibandingkan dengan ukuran WHO. Menurut WHO, kepadatan penduduk normal adalah 9.600 jiwa per $\mathrm{km}^{2}$ (Abraham et all, 2014: 1). Banyaknya penduduk yang mendiami Kota Yogyakarta akan mendorong timbulnya pemukiman kumuh bagi mereka yang tidak bisa mengakses hunian layak.

Menurut data Pemkot, pada tahun 2016 terdapat 177ha atau 6,86\% wilayah kota Yogyakarta yang tergolong kawasan kumuh. Angka ini meningkat bila dibandingkan dengan tahun 2012 di mana terdapat 89,88ha (2,77\%) wilayah kumuh di Kota Yogyakarta. Dengan demikian, dalam periode tersebut luas wilayah kumuh di Kota Yogyakarta mengalami peningkatan dua kali lipat. Kekumuhan wilayah salah satunya berdampak pada jumlah rumah tidak layak huni. Keberadaan rumah tidak layak huni ini banyak dijumpai di wilayah sepanjang tepian sungai, baik Sungai Code, Winongo, maupun Gajahwong, kemudian banyak juga yang berlokasi di sepanjang rel kereta api, kolong-kolong jembatan, atau terminal. Pada tahun 2016, jumlah rumah tidak layak huni mencapai 2.781 unit (Pemerintah Kota Yogyakarta, 2017:114).

Keberadaan Kota Yogyakarta dengan segala permasalahannya membuat persoalan kemiskinan menjadi lebih kompleks. Perhitungan kemiskinan dengan menggunakan Multidimensional Poverty Index (MPI) dinilai cocok diterapkan di Kota Yogyakarta karena metode perhitungan ini lebih komprehensif. Pemerintah Kota Yogyakarta mengamini bahwa masalah kemiskinan tidak hanya terkait dengan persoalan ekonomi semata. Dalam Perda Nomor 11 tahun 2017 disebutkan bahwa kecenderungan kemiskinan di Kota Yogyakarta terjadi karena kurangnya kesempatan, keterbatasan kepemilikan aset/barang, serta akses terhadap pelayanan sosial.

Berbicara mengenai kemiskinan tak lepas dari apa yang dimaksud dengan kesejahteraan. R.S Pindyck mengemukakan bahwa kesejahteraan menjadi antitesis dari kemiskinan yang dialami oleh seseorang (Nuryitmawan, 2016:34). Untuk menilai taraf kesejahteraan masyarakat dalam suatu negara, dilakukan pengukuran kesejahteraan. Pada tataran global, terjadi perdebatan atas pengukuran kesejahteraan mewakili dua kubu dengan orientasi pembangunan yang berbeda. Kubu 
pertama menilai kesejahteraan diukur dari PDB dan pendapatan per kapita. Adapun kubu kedua memandang kesejahteraan harus dilihat dari pembangunan manusia (Rahardjo, 2016: xxix).

Pandangan kubu kedua ini dipelopori oleh dua orang yakni Mahbub U1 Haq dan Amartya Sen (Rahardjo, 2016:xxix). U1 Haq berpendapat bahwa pembangunan harus bisa mengurangi kekurangan gizi, penyakit, buta huruf, kemelaratan, dan perbedaan (U1 Haq, 1983:56).

Amartya Sen menyatakan bahwa asal sejahteranya individu ialah kemampuan untuk bisa berfungsi layak dalam masyarakat. Kondisi sejahtera yang dimaksud adalah saat terpenuhinya kebutuhan dasar akan gizi, pendidikan, perumahan, penghasilan, kebebasan dalam memilih, dan mendapat perlindungan dari risiko yang mengancam hidupnya Nuryitmawan (2016: 34).

Upaya Sen dan U1 Haq untuk menolak PDB sebagai tolok ukut kesejahteraan dilakukan dengan merancang Indeks Pembangunan Manusia (IPM) pada tahun 1990. IPM memuat 3 hal yakni pendapatan per kapita, usia harapan hidup, dan angka partisipasi sekolah sebagai alternatif untuk melihat kesejahteraan. IPM memuat pemikiran bahwa rakyat merupakan kekayaan sebenarbenarnya dari sebuah negara dan pembangunan harus membuat lingkungan yang memungkinkan penghuninya untuk menikmati hidup panjang, sehat, dan berdaya cipta (Fiaramonti, 2017: 127129).

Dari pemaparan di atas terlihat bahwa sejak dulu terjadi perdebatan mengenai pengukuran kesejahteraan. Di satu pihak, kesejahteraan hanya dinilai dari aspek ekonomi semata. Di sisi lain, ada yang berpendapat bahwa kesejahteraan diukur dengan tidak hanya terkait dengan masalah ekonomi, namun terkait dengan hal lain seperti pendidikan dan kesehatan.

Kemiskinan moneter di Indonesia diukur dengan menggunakan standar dari Badan Pusat Statistik (BPS). Menurut BPS, kemiskinan berarti ketidakmampuan dalam memenuhi standar kebutuhan dasar yang meliputi kebutuhan makanan maupun non makanan (Khomsan et al, 2015:12). Cara menetapkan garis kemiskinan adalah dengan melihat besarnya rupiah yang dibelanjakan per kapita per bulan dalam memenuhi kebutuhan pangan dan non pangan. Kebutuhan pangan dipatok pada angka $2.100 \mathrm{kkal} / \mathrm{kapita} / \mathrm{hari}$ sesuai anjuran Widyakarya Pangan dan Gizi 1988 (Khomsan et al, 2015:13).

Pengukuran pendekatan dengan kemiskinan multidimensi muncul karena adanya kritik terhadap pendekatan ekonomi semata dalam mengukur kemiskinan. Konsep ini pada mulanya dikemukakan oleh Amartya Sen yang menyatakan bahwa kemiskinan harus dilihat dari berbagai dimensi (Perkumpulan Prakarsa, 2013: 1).

Sedangkan kemiskinan multidimensi di Indonesia dapat diukur menggunakan 11 indikator yang dikembangkan oleh Perkumpulan Prakarsa. Indikator tersebut adalah sanitasi, air bersih, penolong persalinan, gizi balita, keberlangsungan pendidikan, melek huruf, akses layanan pendidikan pra sekolah, bahan bakar memasak, listrik yang digunakan, atap, dinding, dan lantai rumah, dan kepemilikan rumah.

\section{METODE}

Penelitian ini merupakan penelitian deskriptif. Data yang digunakan merupakan data sekunder yang bersumber dari Survey Ekonomi dan Sosial Nasional (Susenas) BPS 2016. Responden penelitian ini berjumlah 1788 orang yang terdapat dalam $641 \mathrm{KK}$. Metode pengumpulan data yang digunakan adalah metode dokumentasi. Pengukuran kemiskinan moneter menggunakan garis kemiskinan yang ditetapkan oleh BPS. Penduduk miskin moneter didefinisikan sebagai penduduk yang memiliki rata-rata pengeluaran per kapita per bulan di bawah standar yang ditetapkan. Standar yang ditetapkan di Kota Yogyakarta pada tahun 2016 adalah Rp 401.193,-. Adapun pengukuran kemiskinan multidimensi menggunakan metode Alkire-Foster di mana MPI dihitung menggunakan 
bobot tertimbang dari dimensi dan indikator. Dimensi tersebut adalah dimensi pendidikan, kesehatan, dan kualitas hidup. Dimensi kesehatan diukur dengan sanitasi, air bersih, penolong persalinan, dan imunisasi. Sedangkan dimensi pendidikan dilihat dari kehadiran dalam pendidikan, melek huruf, dan akses layanan pendidikan pra sekolah. Adapun dimensi terakhir dimensi kualitas hidup diukur dengan sumber penerangan, bahan bakar untuk memasak, dan kondisi atap, dinding, dan lantai rumah dan kepemilikan rumah. Apabila total rata-rata penilaian lebih besar dari 0,333 maka individu tersebut mengalami miskin multidimensi. Analisis data adalah analisis deskriptif dengan menggunakan tabel, grafik, dan diagram batang.

\section{HASIL DAN PEMBAHASAN}

\section{Kondisi Kemiskinan Moneter di Kota Yogyakarta}

Metode yang digunakan oleh BPS untuk mengukur tingkat kemiskinan adalah pendekatan moneter dengan menggunakan garis kemiskinan. Dalam hal ini garis kemiskinan dilihat dari pengeluaran yang dihabiskan rumah tangga per kapita per bulan. Pada tahun 2016, angka garis kemiskinan sejumlah Rp 401.193,--

Tabel 1. Pengeluaran Menurut Garis Kemiskinan di Kota Yogyakarta

\begin{tabular}{lrr}
\hline \multicolumn{1}{c}{ Pengeluaran/kapita/jiwa } & Jumlah & Persentase \\
\hline Penduduk di bawah garis kemiskinan & 137 & $7.66 \%$ \\
Penduduk di atas garis kemiskinan & 1651 & $92.34 \%$ \\
\hline Total & 1788 & $100.00 \%$ \\
\hline
\end{tabular}

Sumber data: BPS, 2016 data diolah.

Dari hasil perhitungan didapati bahwa sebesar 137 responden di Kota Yogyakarta (7,66\%) mengalami kemiskinan moneter pada tahun 2016. Pengeluaran per kapita mereka berada di bawah garis kemiskinan yang telah ditetapkan. Sementara 1651 responden $(92,34)$ termasuk dalam golongan tidak miskin.

Tingkat kesejahteraan dapat diukur dengan menggunakan pola konsumsi. Semakin sejahtera masyarakat akan membuat proporsi pengeluaran untuk bahan makanan semakin kecil.

Tabel 2. Persentase Pengeluaran Berdasarkan Makanan dan Non Makanan Menurut Garis Kemiskinan di Kota Yogyakarta

\begin{tabular}{lcc}
\hline \multicolumn{1}{c}{ Pengeluaran/kapita/jiwa } & Makanan & Non makanan \\
\hline di bawah garis kemiskinan & $56,31 \%$ & $43,69 \%$ \\
di atas garis kemiskinan & $41,58 \%$ & $58,42 \%$ \\
\hline Total & $42,70 \%$ & $57,30 \%$ \\
\hline
\end{tabular}

Sumber data: BPS, 2016 data diolah.

Penduduk yang hidup di bawah garis kemiskinan menghabiskan sebagian besar pengeluaran untuk membeli makanan. Berbanding terbalik dengan penduduk yang hidup di atas garis kemiskinan. Proporsi pengeluaran mereka untuk membeli bahan makanan lebih kecil dibanding pengeluaran non makanan. Data tersebut menunjukkan bahwa semakin besar pengeluaran maka proporsi untuk pembelian bahan makanan menjadi semakin kecil. Hal ini sesuai dengan hukum Engel yang berbunyi "jika pendapatan meningkat, maka persentase pengeluaran untuk konsumsi pangan semakin kecil". 


\section{Kondisi Kemiskinan Multidimensi di Kota Yogyakarta}

Berdasarkan perhitungan menurut Alkire-Foster maka angka kemiskinan multidimensi Kota Yogyakarta pada tahun 2016 berjumlah 1,39\%. Adapun Indeks kemiskinan multidimensi di Kota Yogyakarta tahun 2016 berada di angka 0,00487. Perhitungan tiap indikator akan menghasilkan angka kemiskinan yang berbeda.

Tabel 3. Perhitungan Kemiskinan Multidimensi di Kota Yogyakarta Tahun 2016

\begin{tabular}{lcccc}
\multirow{2}{*}{ Indikator } & \multicolumn{2}{c}{ Frekuensi } & \multicolumn{2}{c}{ Persentase } \\
\cline { 2 - 5 } & Miskin & tidak miskin & miskin & tidak miskin \\
\hline Kepemilikan rumah & 864 & 924 & $48,32 \%$ & $51.68 \%$ \\
Air Bersih & 800 & 988 & $44,74 \%$ & $55,26 \%$ \\
Kalori & 227 & 1.561 & $12,70 \%$ & $87,30 \%$ \\
pendidikan pra sekolah & 105 & 1.683 & $5,87 \%$ & $94,13 \%$ \\
Sanitasi & 84 & 1.704 & $4,70 \%$ & $95,30 \%$ \\
Bahan bakar memasak & 63 & 1.715 & $3,52 \%$ & $96,48 \%$ \\
melek huruf & 14 & 1.774 & $0,78 \%$ & $99,22 \%$ \\
Keberlangsungan pendidikan & 4 & 1.784 & $0,22 \%$ & $99.78 \%$ \\
Penolong persalinan & 3 & 1.785 & $0.17 \%$ & $99.83 \%$ \\
Sumber penerangan & 1 & 1.787 & $0,06 \%$ & $99.94 \%$ \\
Atap, dinding, lantai & 0 & 1.788 & $0.00 \%$ & $100.00 \%$ \\
\hline
\end{tabular}

Sumber data: BPS, 2016 data diolah.

Dari tabel 3 dapat diketahui kemiskinan paling tinggi terjadi pada indikator kepemilikan rumah. Hampir separuh responden tidak memiliki tempat tinggal sendiri. Sementara kemiskinan terendah terjadi pada indikator atap, dinding, dan lantai rumah di mana tidak ada satu pun responden yang mengalami kemiskinan pada indikator tersebut. Tingginya kemiskinan pada akses terhadap kepemilikan rumah tak lepas dari luas wilayah Kota Yogyakarta yang hanya $32,5 \mathrm{~km}^{2}$. Sementara jumlah penduduk Kota Yogyakarta pada tahun 2015 mencapai 412.704 jiwa dengan rincian sebanyak 201.082 jiwa penduduk laki-laki dan 211.622 jiwa penduduk perempuan. Dengan luas wilayah 32,50 km², kepadatan penduduk Kota Yogyakarta tahun 2015 sebesar 12.699 jiwa per $\mathrm{km}^{2}$ (BPS, 2017: 67). Angka kepadatan penduduk tersebut merupakan yang paling tinggi di antara daerah lain di Provinsi Daerah Istimewa Yogyakarta.

\section{Perbandingan Kemiskinan Moneter dan Multidimensi di Kota Yogyakarta}

Angka kemiskinan multidimensi tahun 2016 lebih rendah bila dibandingkan dengan kemiskinan moneter. Pada tahun tersebut, angka kemiskinan multidimensi adalah 1,39\% sedangkan jumlah penduduk miskin moneter mencapai 7,66\%.

Tabel 4. Perbandingan Angka Kemiskinan Moneter dan Multidimensi Tahun 2016

\begin{tabular}{ccc}
\hline & $\begin{array}{c}\text { Persentase } \\
\text { Rumah Tangga Miskin }\end{array}$ & $\begin{array}{c}\text { Persentase } \\
\text { Penduduk Miskin }\end{array}$ \\
\hline Kemiskinan moneter & $7.64 \%$ & $7.66 \%$ \\
Kemiskinan multidimensi & $1.56 \%$ & $1.39 \%$ \\
\hline
\end{tabular}

Sumber data: BPS, 2016 data diolah. 
Pada tahun 2016, jumlah rumah tangga yang mengalami miskin multidimensi sebanyak $1,56 \%$ sedangkan penduduk yang mengalami kemiskinan multidimensi sejumlah 1,39\%. Angka ini lebih rendah bila melihat tingkat kemiskinan moneter. Di tahun yang sama, terdapat 7,64\% rumah tangga yang mengalami kemiskinan moneter di Kota Yogyakarta. Sementara penduduk yang mengalami kemiskinan multidimensi mencapai 7,66\%.

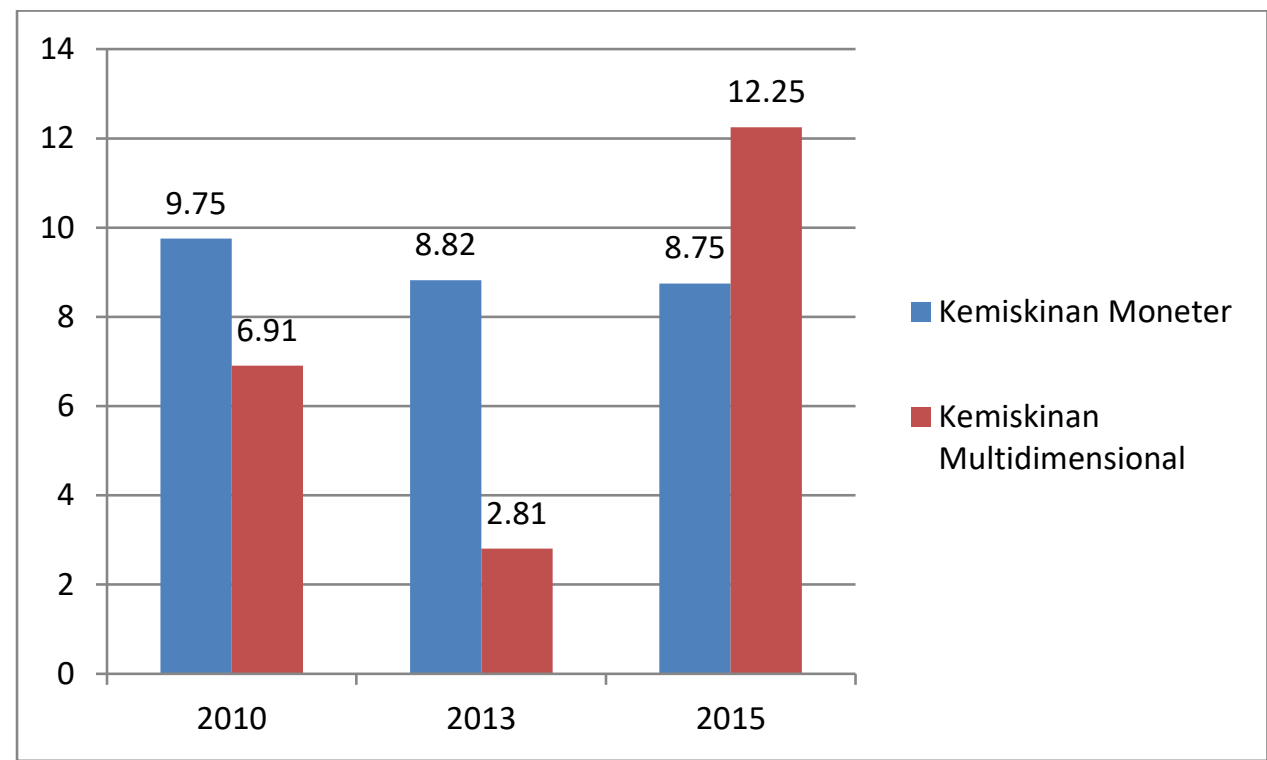

Gambar 1. Perbandingan Antara Tingkat Kemiskinan Moneter dengan Multidimensi di Kota Yogyakarta 2010, 2013, dan 2015

Jumlah kemiskinan moneter selalu lebih tinggi dibandingkan dengan jumlah kemiskinan multidimensi. Kecuali pada tahun 2015 di mana angka kemiskinan multidimensi lebih tinggi dibandingkan dengan kemiskinan moneter.

\section{SIMPULAN}

Perbandingan kemiskinan moneter dan multidimensi menunjukkan bahwa angka kemiskinan moneter lebih tinggi dibandingkan dengan kemiskinan multidimensi. Kemiskinan moneter di Yogyakarta dihitung dengan menggunakan garis kemiskinan yang sejumlah Rp401.193,00/kapita/bulan. Dari hasil perhitungan sebanyak 7,66\% penduduk Kota Yogyakarta mengalami kemiskinan moneter. Angka kemiskinan multidimensi di Kota Yogyakarta pada tahun 2016 mencapai 1,39\% dengan indeks kemiskinan multidimensi 0,00487. Dari berbagai indikator dalam pengukuran kemiskinan multidimensi indikator tertinggi adalah kepemilikan rumah di mana sebanyak 48,32\% penduduk mengalami kemiskinan pada indikator tersebut.

Pemerintah Kota Yogyakarta harus senantiasa memperhatikan masalah kemiskinan tidak hanya dari dimensi moneter melainkan multidimensi. Pemerintah Kota Yogyakarta perlu memikirkan kebijakan agar penduduk Kota Yogyakarta yang tidak mampu mengakses kepemilikan rumah untuk memiliki rumah sendiri. Lahan yang terbatas dan harga tanah yang mahal menjadi kendala utama. Penyediaan rumah susun menjadi salah satu solusi untuk mengatasi permasalahan tersebut. Pemerintah perlu bersinergi dengan lembaga sosial dan instansi swasta dalam hal pemberian bantuan bagi warga miskin agar mereka dapat meningkatkan kualitas kehidupannya. 


\section{DAFTAR PUSTAKA}

Abraham, Razii, et all. (2014). Visa Masuk Kota: Alternatif Kebijakan Kaum Urban Untuk Mengatasi Kepadatan Penduduk Jakarta. PKM-GT Kemenristek Dikti.

Alkire, Sabina, et all.(2015). Multidimensional Poverty Measurement and Analysis. Oxford University Press: New York.

Badan Pusat Statistik Kota Yogyakarta. (2017). Kota Yogyakarta Dalam Angka 2017. Yogyakarta: Badan Pusat Statistik Kota Yogyakarta

Fiaramonti, L. (2017). Problem Domestik Bruto (Terjemahan Lita Soerjadinata). Tangerang Selatan: Marjin Kiri. (Edisi asli diterbitkan tahun 2013 oleh Zed Books Ltd. London.

U1 Haq, M. (1983). Tirai Kemiskinan, Tantangan-tantangan untuk Dunia Ketiga (Terjemahan Masri Maris). Jakarta: Yayasan Obor Indonesia. (Edisi asli diterbitkan tahun 1976 oleh Columbia University Press).

Iryanti, R. (2016). Strategi Nasional Dalam Pencapaian Target Pengurangan Kemiskinan Tahun 2019.

Khomsan, Ali, et all. (2015). Indikator Kemiskinan dan Misklasifikasi Orang Miskin. Jakarta: Yayasan Obor Indonesia

Nuryitmawan, T. R. (2016). Studi Komparasi Kemiskinan di Indonesia: Multidimensional Poverty dan Monetary Poverty. Jurnal Ilmu Ekonomi Terapan, Juni 2016 Hal 33-41, ISSN: 2528-1879.

Pemerintah Kota Yogyakarta. (2017). Peraturan Daerah Kota Yogyakarta Nomor 11, Tahun 2017, tentang Rencana Pembangunan Jangka Menengah Daerah 2017-2022

Perkumpulan Prakarsa. (2013). Multidimensi Poverty Index (MPI): Konsep dan Pengukurannya di Indonesia. Diakses online melalui http://theprakarsa.org/new/ck_uploads/files/MPI\%20INDONESIA_CY_20_06_13.pdf

Rahardjo, D. (2016). Kebijakan Kesejahteraan Sosial Dalam Satu Dasawarsa Terakhir. Dalam Ah, Maftuchan, Mickael B Hoelman, \& Victoria Fanggidae (Eds). Transformasi Kesejahteraan, Pemenuhan Hak Ekonomi dan Kesehatan Manusia (pp.xxv-xxxviii). Jakarta: LP3ES.

Ras. A. (2013). Pemberdayaan Masyarakat Sebagai Upaya Pengentasan Kemiskinan. Jurnal Socius, Oktober-Desember $2013 \mathrm{Hal}$ 56-63. 